\title{
The Role of Stability and Renegotiation in Transnational Petroleum Agreements
}

\author{
Hadiza Tijjani Mato \\ Faculty of Law \\ University of Abuja, Nigeria \\ Tel: 23-480-3612-8319Ｅ-mail: hadmato@yahoo.com
}

Received: September 7, 2011

Accepted: October 8, $2011 \quad$ Published: March 1, 2012

doi:10.5539/jpl.v5n1p33

URL: http://dx.doi.org/10.5539/jpl.v5n1p33

\begin{abstract}
Stability of existing agreements is the major means of investment protection at the disposal of multinational oil companies. This is achieved by inserting stabilization clauses to ensure that future changes in policy or legislation of the host country does not affect the existing agreement. Multinational oil companies are nevertheless confronted by the reality that stabilization clauses do not in fact provide the requisite immunity against host government action. On the part of host countries, it is recognized that their right to enjoy maximum benefits and to avoid adverse consequences from the exploitation of petroleum cannot be compromised on the ground that stability is an express term of the agreement. Therefore, renegotiation in the event of a fundamental change of circumstances surrounding the agreement appears to be a viable option for both parties to a petroleum agreement. Hence, this research examines the twin concepts of stability and renegotiation and their significance in international petroleum contracts.
\end{abstract}

Keywords: Stability, Renegotiation, Transnational, Petroleum, Agreements

\section{Introduction}

The emergence of the New International Economic Order led to the evolution and consequent general international acceptance of the principle of permanent sovereignty over Natural resources (Note 1). This gave birth to an era of resource nationalism in natural resources-endowed countries (Note 2). In particular, developing countries took all steps necessary to ensure that they derive maximum benefit from the exploitation of their natural resources. In this regard, transnational mining agreements became the most viable option. This is more so with respect to petroleum exploitation where capital and expertise requirement is relatively high, usually beyond the affordability of developing countries (Note 3). Contractual relationship with multinational oil companies became inevitable.

A major source of conflict between host governments of developing countries and multinational oil companies derives from the preoccupation of multinational oil companies with stability and predictability in contractual relations on the one hand, and the persistent demands of host governments for a more flexible contractual regime on the other (Note 4). This is because the underlying objectives of the two parties are significantly divergent. While host governments aim at promoting economic growth and development through such foreign investment, the multinationals are merely concerned with maximization of profit at the least risk (Note 5).

\section{Nature of Transnational Petroleum Agreements}

The relations between developing countries and multinational oil companies are often embodied in long-term agreements which may be concessions, joint venture agreements, production-sharing agreements, risk service agreements and so on. These agreements exhibit peculiar features. The first feature is their long-term character; the activities of the investor in the host country, from exploration to the development and finally decommissioning (Note 6), can only be performed over a very long period of time (Note 7). The second feature is that they are capital intensive contracts (Note 8). The third feature is the high risk of operations in the petroleum exploitation. Such risk is usually taken by the multinational oil company upon a reasonable expectation of the promise of a high profit return (Note 9). These risks include the geological, commercial, technical, managerial, natural disaster risks, and last but definitely not least, the political risk. One particular risk must however be pointed out: the risk of changes in the regulatory regime leading to total or partial expropriation (Note 10).

\subsection{Pacta Sunt Servanda}

It may be recalled that pacta sunt servanda is a fundamental principle of law, the effect of which is that contractual 
obligations must be respected (Note 11). This principle has also been recognized in the specific context of petroleum agreements. Today, it is widely held that the international minimum standard of protection to be afforded by a host State to a foreign investor and its investments in the territory of the host State encompasses the requirement of good faith (Note 12). Nevertheless, it is generally accepted that concessions for the exploitation of natural resources are contracts that can be breached under international law (Note 13). This is because although an examination of the major representative legal systems of the world shows that the principle of pacta sunt servanda or strict sanctity of contract is widely accepted, under no legal system has the principle been found to be absolute (Note 14). It has also been held that the contractual rights contained in the concession can be expropriated (Note 15). Expropriation is among the most extreme measures a host country can adopt regarding foreign investment, and consequently represents a special concern to foreign investors, may it be an outright, partial or "creeping" expropriation (Note 16).

It is consequently natural that investors seek protection against the risks investment contracts will be subject to during its long life. Investors use risk management often, which may include (i) spreading the risk by associating other parties to the venture, such as banks and industry partners, and/or by diversifying operations; (ii) obtaining a political risk insurance (iii) defending against risk through legitimate pressure mechanisms, such as diplomatic intervention or economic and financial persuasion; or (iv) structuring and managing the venture by associating the host country or NOC to the venture, keeping a low visibility and/or putting across an image of fairness and understanding of the host country's social and economic problems. Investors however prefer to rely on stabilization by contract to better protect their interests in such long-term investment contracts from political risk, namely by including in it a stabilization clause (Note 17).

\section{Stability in Transnational Petroleum Agreements}

In petroleum agreements, stability is achieved through stabilization clauses. This is aimed at protecting the Multinational Oil Companies, as private investors by restricting the legislative or administrative power of the Host State, as sovereign in its country and legislator in its own legal system, from amending the contractual regulation or even to annul the agreement (Note 18).

\subsection{Stabilization Clauses}

Stability may be ensured by providing that:

i. "The agreement takes precedence over any provisions enacted subsequent thereto by way of legislation or administrative regulation if the effect of such provisions is to the investor's prejudice, a result that may be achieved only by conferring to the agreement of the force of law so that its provisions may not be modified by general legislation;

ii. Any modifications of the terms and conditions of the agreement may only be made by mutual written consent of the parties, the effectiveness of this kind of provision depending again upon the agreement having acquired the force of law; or

iii. The law applicable to the development agreement is the law of the host State in force at the time of the conclusion of the contract, thus excluding the applicability of any future laws and regulations (a provision referred to as freezing of the law)." (Note 19)

Stabilization clauses are in particular directed against: (1) the raising of taxes beyond the rates operating at the time of the agreement or otherwise stipulated in the agreement. (2) The imposition of any fiscal changes in the general industrial or commercial sectors in excess of the fiscal charges provided in the agreement. (3) The amendment of the laws, such as corporate and tax laws, which were in force on the date of the agreement. (4) Expropriation, nationalization and any other form of intervention in the enterprise (Note 20).

\subsection{Legal Status of Stabilization Clauses}

The legality and binding nature of stabilization clauses was upheld in Texaco v. Libya, Kuwait v. Aminoil, and AGIP v. Congo. This reflects the general trend in international arbitral practice. The basis of the stabilization clause is that the state is bound by the agreement contained in the clause not to apply any later changes to its law to the particular contract or to alter the terms of the contract directly by legislation (Note 21). The point of contention however is whether a contractual clause can achieve the effect of fettering the legislative sovereignty of a state (Note 22). This is because it is trite law that a legislature is not bound by its own legislation and has the power to change it. Moreover, the legislative powers of a state cannot be fettered by a mere contractual provision, particularly where the exercise of that power is necessary to protect an overriding public interest. Even when a stabilization clause can be upheld under international law, this would of course not detract from the factual power of the host country's government to act in breach of it by changing the investment conditions. But this does not imply that stabilization clauses are useless. They have a 'functional value' in that they strengthen the private contractor's bargaining position. 
In case of breach by the State of the undertaking under a stabilization clause, an arbitral award may enjoin the State to refrain from applying the new laws and regulations to the private party or may condemn it to compensate the latter for the economic prejudice suffered because of the breach of such an undertaking (Note 23). Although in this context the State might raise before an international arbitrator the defence regarding the inalienable character of its sovereign rights in order to void the clause of its effects, the reliance created in the private party by the State's promise is a sufficient strong argument to convince the international arbitrator that the foreign investor is entitled to compensation for any damage so caused, even if the breach by the State of its stabilization commitment might not be qualified as internationally unlawful (Note 24).

In AGIP Co. SpA v. Government of the Popular Republic of Congo (Note 25) the arbitral tribunal held that the nationalization that was the subject-matter of the dispute violated both domestic and international law because it breached the stabilization clause contained in the agreement. The arbitral tribunal stated:

These stabilization clauses, freely accepted by the Government, do not affect the principle of its sovereign legislative and regulatory powers, since it retains both in relation to those, whether national or foreigners, with whom it has not entered into such obligations, and that, in the present case, changes in the legislative and regulatory agreements stipulated in the agreement simply cannot be invoked against the other contracting party (Note 26).

In Texaco v. Libya (Note 27), the sole arbitrator also dealt with a stabilization clause included in the concession agreement. The clause provided that the concession would be construed according to the regulatory framework in effect at the time it was granted and no changes in the legal system would apply without the parties' agreement. In the arbitrator's opinion, although Libya could nationalize other investors' property according to its sovereign powers, it could not nationalize contractual rights protected by a stabilization clause.

In effect, arbitration practice demonstrates that in the presence of an express commitment not to alter the parties' legal relationship, a State cannot invoke its sovereignty to disregard obligations acquired with respect to foreign investors. In addition, it cannot, through measures based on its domestic law, terminate or substantially affect the contractual rights of the investor (Note 28). Undoubtedly, a long line of international jurisprudence demonstrates that state promises to foreign investors have been strongly enforceable as a matter of consistent international law and practice (Note 29). Providing the justification for this position, the arbitral tribunal in Revere Copper v. OPIC (Note 29a) held:

under international law the commitments made in favor of foreign nationals are binding notwithstanding the power of Parliament and other governmental organs under the domestic Constitution to override or nullify such commitments.

\section{Renegotiation}

Doubts concerning the legal effectiveness of stabilization clauses and the State's desire to preserve its sovereign prerogatives have brought about a new approach providing that if future laws or regulations enacted by the host State should affect the foreign investor's contractual position, negotiations shall be entered into in good faith in order to reach an equitable solution to maintain or restore the economic equilibrium of the agreement. The renegotiation clause may offer both parties protection against the hardship caused to either of them by a change of those circumstances which were present at the time of the conclusion of the agreement. By undertaking to renegotiate in good faith the agreement in case of any such change, the State binds itself to conduct negotiations with the foreign investor instead of unilaterally altering the terms of the agreement (Note 30).

Renegotiation clauses usually provide that any law, regulation or any other government act subsequent to the original contract that negatively affects the investor's contractual interests will entitle him the right to request for the contract renegotiation and that the host country will have the obligation of entering in such renegotiations in good faith. A typical renegotiation clause will provide that either the host government or foreign investor has the right to request for the contract adaptation if its equilibrium is negatively affected under the occurrence of an event that is beyond the control of both parties.

\subsection{Ground for Renegotiation}

Renegotiation of existing transnational investments agreements is in general a reflection of fundamental changes in the economic environment affecting the equilibrium of the agreement (Note 31). This change of circumstances (expressed as clausula rebus sic stantibus), generally accepted under international law is a basis for eventual adjustment and even termination of the agreement in case of a change in the fundamental condition on which the agreement was based (Note 32).

In order for renegotiation clauses to work properly, it must be assured that the contract offers a clear definition of: (i) changes of circumstances (ii) what effect on the contract should trigger the right to request for a renegotiation; and 
(iii) objective of the renegotiation (Note 33). Practice shows however that providing for clear and unambiguous definitions is not an easy task. Wordings such as "a substantial change in the circumstances existing on the date of the agreement" or simply "a change of circumstances", "disproportionate prejudice" or "substantial economical imbalance" and "removing the unfairness from the contract" or "restoring the economic equilibrium of the contract" are commonly found (Note 34).

In Gabcikovo-Nagymaros Case (Note 35), Hungary sought to rely on, among others, the principles of impossibility of performance and the occurrence of a fundamental change of circumstance as grounds to withdraw from its treaty obligations. Whilst reinforcing the principle of pacta sunt servanda, the decision in that case also suggests that an unforeseen fundamental change which affects the basis of an agreement could be a ground for renegotiating the agreement. This is confirmed by the court's observation that newly developed norms of environmental law had to be taken into consideration by the parties in implementing the treaty. It therefore, called on the parties to enter into good faith renegotiation to re-examine the effects of the project on the environment, and to reach a satisfactory solution that takes account of the objectives of the treaty (Note 36).

\section{Conclusion}

Although nation states are at liberty to determine the manner by which petroleum to which they lawfully lay claim should be exploited, it is not in the national interest to undermine the positive socio-economic relevance of transnational oil companies. Petroleum agreements provide the platform for mutually beneficial relationship between host countries and multinational oil companies. This symbiosis can only be realized through carefully drafted agreement between the parties. In addition, while ensuring that parties are bound to fulfill their part of the bargain, there should be room for negotiations in the event of an occurring disequilibrium affecting the economic condition surrounding the agreement. Here again, the element of good faith must be observed at all times, having as a core aim, restoring the balance of the agreement.

\section{Key Findings and Recommendations}

\subsection{Petroleum Agreements versus Quest for Sovereignty over Petroleum Resources}

Among the existing principles of international law that developing countries attempted to diminish was the principle of pacta sunt servanda underlying contractual commitments. They argued that their sovereignty over natural resources superseded any contractual promise, including express commitments by the State not to impair those contractual rights (Note 37). Furthermore, they proposed that any agreement with a foreign investor was subject to modification or termination based on national interest motives alone (Note 38).

This quest for sovereignty has received international acceptance for it is generally recognized that respect for contractual obligations does not imply that a State cannot exercise its sovereignty to adopt laws or regulations within its accepted powers even if such measures may cause economic damage to those subject to its powers (Note 39). In these cases, the injured party may not have the right to compensation (Note 40). The point to ponder over however, is whether such excessive exercise of state sovereignty is in fact advantageous to healthy economic development. Perhaps, the example of the Venezuela oil nationalism (Note 41) makes this point relevant. Since 2004, the Venezuelan government has been implementing its most significant oil field nationalization process in 30 years (Note 42). Pursuant to a proclaimed right to 'oil sovereignty', Venezuela has taken actions that can be perceived as detrimental to multinational oil investors (Note 43), ranging from unilateral increases in taxes and royalties, to forced contract renegotiations, nullification of contracts and outright expropriations. These actions of the government have resulted in squeezing multinational oil companies out of a national oil industry that is still in need of substantial petroleum agreement to fulfill its potential. In addition to concerns that PDVSA (Note 44) has over extended itself, there are also questions as to whether the current policies will dampen future investment in Venezuela. Why should international oil companies risk investing in the volatile Venezuelan oil industry? How confident can potential investors be that Venezuela will honor contracts instead of changing the rules of the game once the initial investment is made?

It is worth stating here that the overall benefits of foreign investment for developing country economies cannot be overemphasized. Given the appropriate host-country policies and a basic level of development, a preponderance of studies shows that foreign investment triggers technology spillovers, assists human capital formation, contributes to international trade integration, helps create a more competitive business environment and enhances enterprise development (Note 45). All of these contribute to higher economic growth, which is the most potent tool for alleviating poverty in developing countries. Moreover, beyond the strictly economic benefits, foreign investment may help improve environmental and social conditions in the host country by, for example, transferring "cleaner" technologies and leading to more socially responsible corporate policies (Note 46). 
Yet, these benefits do not accrue automatically. Conducive national policies on petroleum agreements are important for attracting foreign investment to developing countries and for reaping their full benefits for development. Host countries need to establish a transparent, broad and effective enabling policy environment for investment and this must include reasonable contractual commitments. In this respect, renegotiation clauses become important tools in the pursuit of state sovereignty since it has in many cases increased host countries' participation in petroleum development (Note 47). The aim should always be to maximize the benefits and minimize the costs (Note 48).

\subsection{Defining Fundamental Change of Circumstances}

The major concern of the multinational oil firms is not with the renegotiation clause but rather with the fear that the flexibility created by the insertion of the renegotiation clause could be used by the state to alter key investment conditions to its advantage (Note 49). An imprecise definition of what constitutes a fundamental change of circumstance could leave room for manipulations in contractual relations. It may also create conflicts over whether or not a triggering event has occurred.

Expressed as clausula rebus sic stantibus, fundamental change of circumstances is an escape clause that makes an exception to the general rule of pacta sunt servanda. The change of circumstances triggering renegotiation lacks standard definition but the concept has nevertheless gained wide acceptance in practice (Note 50) and is often embodied in renegotiation clauses. For example Petroleum production agreement between the Government of Ghana and Shell Exploration and Production Co. provides:

It is hereby agreed that if during the term of this Agreement there should occur such changes in the financial and economic circumstances relating to the petroleum industry, operating conditions in Ghana and marketing conditions generally as to materially affect the fundamental economic and financial basis of this Agreement, then the provisions of this Agreement may be reviewed or renegotiated.... (Note 51)

The Vienna Convention on the Law of Treaties of 1969, where such principle is expressed, does not define what a "fundamental change of circumstances" is, but rather states that such change cannot be invoked as ground for termination or withdrawal from a treaty, except when such circumstances:

a) constituted an essential basis of the consent of the parties to the treaty; and

b) the effect of the change is radically to transform the extent of obligations still to be performed under the treaty (Note 52)

In interpreting this section, the International Court of Justice (ICJ) has taken a very restrictive approach on what amounts to a fundamental change of circumstance. This is illustrated by the Gabcikovo-Nagymaros Case, in which Hungary sought to rely on, among others, the principles of impossibility of performance and the occurrence of a fundamental change of circumstance as grounds to withdraw from its treaty obligations. These included political changes in both Hungary and Slovakia, the project's diminishing economic viability, and the progress in knowledge on the environment, and development of new norms of international environmental law. In its decision, the court acknowledged that new norms and standards have been developed since the treaty was signed. Nonetheless, it did not consider that new developments in the state of environmental knowledge and environmental law can be said to have been completely unforeseen. The changed circumstances advanced by Hungary are, in the court's view, not of such a nature, either individually or collectively, that their effect would radically transform the extent of the obligations still to be performed in order to accomplish the project.

A combined reading of Article 62 of the Vienna Convention and the decision in Gabcikovo-Nagymaros Case throws more light on the conditions to be fulfilled. First, the change must be of circumstances existing at the time the treaty was made. Second, the change of circumstances must be "fundamental." Third, the change must not have been foreseen by the parties. Fourth, the existence of those circumstances must have constituted an essential basis of the consent of the parties to be bound by the treaty in the first place. Fifth, the effect of the change must be radically to transform the "extent" of obligations still to be performed under the treaty.

It is thus submitted that the term should be carefully worded and defined in a variety of ways having, as a common denominator, the conditions that the change must be such as to cause a disproportionate prejudice or substantial detriment or substantial economic imbalance to the interests of one of the parties or to materially affect the economic and financial basis of the agreement or the consequences and effects of which are fundamentally different to what was contemplated by the parties at the time of entering the agreement (Note 53).

\subsection{Renegotiation in the Absence of Renegotiation Clause}

Renegotiation is beneficial in a number of ways. To host governments, it provides a medium for revision of contractual terms to meet changed economic conditions that could not have been reasonably foreseen at the time of concluding the agreement. For multinational oil companies, renegotiation ensures security of investment by 
preventing unilateral adaptation of contractual terms by the government. To take advantage of these benefits, parties usually insert renegotiation clauses. In other words, parties to international investment contracts can overcome the pacta sunt servanda principle only if the contract contains a renegotiation clause (Note 54). The pertinent question however, is can a party seek a renegotiation of contractual terms where an express renegotiation clause is not embodied in the agreement?

It may be recalled that by Resolution No. XVI. 90 of 1968, OPEC declared that governments have a right to renegotiate contracts with multinational oil companies (Note 55). In addition, the Draft United Nations Code of Conduct on Multinational oil companies provides thus:

In the absence of contractual clauses providing for review or renegotiation, multinational oil companies should respond positively to requests for review or renegotiation of contracts concluded with Governments or governmental agencies in circumstances marked by duress, or clear inequality between the parties, or where the conditions upon which such a contract was based have fundamentally changed, causing thereby unforeseen major distortions in the relations between the parties and thus rendering the contract unfair or oppressive to either of the parties. Aiming at ensuring fairness to all parties concerned, review or renegotiation in such situations should be undertaken in accordance with applicable legal principles and generally recognized legal practices (Note 56)

The attitude of many host governments to the issue of renegotiation is reflected in the following statement of US Secretary of the Interior, Ken Salazar to an oil industry audience:

Just as your shareholders expect you to get a fair rate of return on your investments and to be wise stewards of your balance sheets, the American people are asking the same of us as we manage their resources. . . That means we are going to take another look at royalty rates. It means that tax breaks that are no longer needed, and which the American people can't afford, will disappear (Note 57).

It is therefore advisable that even in the absence of a renegotiation clause, the parties to a transnational petroleum agreement should view renegotiation as a desirable phenomenon whenever the need for it arises. It should be seen as a duty albeit with corresponding obligations. One such obligation is to seek to maintain the original equilibrium of the agreement and not to make one party to secure profits or other benefits at the expense of the other. Again, renegotiation should aim at adapting the agreement to the established changed circumstances and not attempt a reformation of the entire agreement. Hence, one cannot but agree with the words of wisdom that:

Renegotiation should therefore be acknowledged as an Integral feature of the petroleum agreement process (Note 58).

\section{References}

Al Qurashi, Z. A. (2005). "Renegotiation of International Petroleum Agreements". Journal of International Arbitration, (On-line serial) 22(4). [Online] Available: https://is.muni.cz/www/210560/23073893/Qurashi-Renegotiation.pdf

Asante, S. K. B. (1979). "Stability of Contractual Relations in the Transnational Investment Process" The International and Comparative Law Quarterly. Anline] Available: journals.cambridge.org/production/action/cjoGetFulltext?fulltextid...

Bartels, M. (1985). Contractual Adaptation and Conflict Resolution, The Netherlands: Kluwer B. V. Berger, K. P., "Renegotiation and Adaptation of International Investment Contracts: The Role of Contract Drafters and Arbitrators" Vanderbilt Journal Of Transnational Law. [Online] Available: law.vanderbilt.edu/publications/journal-of...4/download.aspx?...

Bernardini, P. (2008). "Stabilization and Adaptation in Oil and Gas Investments". Journal of World Energy Law \& Business. [Online] Available: welb.oxfordjournals.org/content/1/1/98.extract

Eljuri, E. et al. (2009). "Venezuela: On the Path to Complete 'Oil Sovereignty' or the Beginning of a New Era of Investment?" Journal of World Energy Law and Business. [Online] Available: jwelb.oxfordjournals.org/content/2/3/259.extract

Gao, Z. (1994). International Petroleum Contracts: Current Trends and New Direction. London: Graham \& Trotman/Martinus Nijhoff.

Garcia-Amador, F. V. (1980). “The Proposed New International Economic Order: A New Approach to the Law Gidado, M. M. (1999). Petroleum Development Contracts with Multinational Oil Firms: the Nigerian Example.

Governing Nationalization and Compensation" Lawyer of the Americas. [Online] Available: 
www.jstor.org/stable/40175867

Igiehon, M.O., \& Flávia Kaczelnik Altit. "Decommissioning of upstream oil and gas facilities". [Online] Available: http://www.globelawandbusiness.com/OG/sample.pdf Kahale, G. "The Uproar Surrounding Petroleum Contract Renegotiations." [Online] Available: http://omanlawblog.curtis.com/

Macedo, J. (2010). "From Tradition To Modernity: Not Necessarily An Evolution - The Case Of Stabilisation An $\begin{array}{ll}\text { Renegotiation Clauses". } & \text { [Online] } \\ \text { http://www.dundee.ac.uk/cepmlp/gateway/files.php?file=cepmlp car14 } 25 \ldots\end{array}$ Available:

Newcombe, A. P. (1999). "Regulatory Expropriation, Investment Protection and International Law: When is Government Regulation Expropriatory and When Should Compensation be Paid?" [Online] Available: http://italaw.com/documents/RegulatoryExpropriation.pdf

Okogu, B. E. (2003). “The Middle East and North Africa in a Changing Oil Market”. International Monetary Fund . [Online] Available: http://www.imf.org/external/pubs/ft/med/2003/eng/okogu/okogu.htm.

Sornarajah, M. (1996). The International Law on Foreign Investment. New York: Cambridge University Press

Stevens, P. (2008). "National Oil Companies And International Oil Companies In The Middle East: Under The Shadow Of Government And The Resource Nationalism Cycle". Journal of World Energy Law and Business, [Online] Available: jwelb.oxfordjournals.org/content/1/1/5.extract

Vielleville, D. E. et al. (2008). "Sovereignty over Natural Resources Versus Rights under Investment Contracts: Which One Prevails?" Transnational Dispute Management. [Online] Available: http://www.crowell.com/documents/Sovereignty-Over-Natural-Resources-Versus-Rights-Under-Investment Contracts_Transnational-Dispute-Management.pdf

Walde, T. W. (1978). "Revision of Transnational Investment Agreements: Contractual Flexibility in Natural Resources Development" Lawyer of the Americas. [Online] Available: http://www.jstor.org/stable/40175798.

Walde, T. W. (1989). "Permanent Sovereignty over Natural Resources: Recent Developments in the Mineral Sector". United Nations Natural Resources Forum. [Online] Available: http://onlinelibrary.wiley.com/doi/10.1111/j.1477-8947.1983.tb00265.x/pdf

Witten, E. A. (2008).“Arbitration of Venezuelan Oil Contracts: A Losing Strategy?” Texas Journal of Oil, Gas, And Energy Law. [Online] Available: http://www.tjogel.org/archive/Vol4No1/witten.pdf.

Yackee, J. W. (2009). "Pacta Sunt Servanda And State Promises To Foreign Investors Before Bilateral Investment Treaties: Myth And Reality" Fordham International Law Journal. [Online] Available: ir.lawnet.fordham.edu/cgi/viewcontent.cgi?article $=2165 \&$ context...

Yannaca-Small, K. (2008). "Interpretation of the Umbrella Clause in Investment Agreements" In International Investment Law: Understanding Concepts and Tracking Innovations, OECD. [Online] Available: http://www.oecd.org/dataoecd/3/6/40471535.pdf

\section{Notes}

Note 1. Garcia-Amador, F. V. (1980). "The Proposed New International Economic Order: A New Approach to the Law Governing Nationalization and Compensation". Lawyer of the Americas (On-line serial) 12 (1), 13. Available: www.jstor.org/stable/40175867

Note 2. Stevens, P. (2008). "National Oil Companies And International Oil Companies In The Middle East: Under The Shadow Of Government And The Resource Nationalism Cycle". Journal of World Energy Law and Business (On-line serial) 1(1). Available: jwelb.oxfordjournals.org/content/1/1/5.extract

Note 3. Gidado, M. M. (1999). Petroleum Development Contracts with Multinational Oil Firms: the Nigerian Example. Ed-Linform: Maidugur-Nigeria.

Note 4. Asante, S. K. B. "Stability of Contractual Relations in the Transnational Investment Process". The International and Comparative Law Quarterly, (On-line serial) 28(3). Available: journals.cambridge.org/production/action/cjoGetFulltext?fulltextid...

Note 5. Gao, Z. (1994). International Petroleum Contracts: Current Trends and New Direction. London: Graham \& Trotman/Martinus Nijhoff. P. 1

Note 6. Decommissioning describes the set of activities to be undertaken to manage and dispose of installations and platforms and eliminate environmental footprint once an oil producing field is nearing or reaches the end of its economic life. See Igiehon, M.O. \& Flávia Kaczelnik Altit. "Decommissioning of upstream oil and gas facilities". 
(www page) URL http://www.globelawandbusiness.com/OG/sample.pdf

Note 7. Macedo, J. (2010). "From Tradition To Modernity: Not Necessarily An Evolution - The Case Of Stabilisation And Renegotiation Clauses". (www page) URL http://www.dundee.ac.uk/cepmlp/gateway/files.php?file=cepmlp_car14_25

Note8. Gidado, M. M. Supra, note 3.

Note 9. Macedo, J. supra, note 7.

Note 10. Newcombe, A. (1999). "Regulatory Expropriation, Investment Protection and International Law". (www page) URL http://italaw.com/documents/RegulatoryExpropriation.pdf

Note 11. Also referred to as the Umbrella Clause. See Yannaca-Small, K. (2008) "Interpretation of the Umbrella Clause in Investment Agreements". In International Investment Law: Understanding Concepts and Tracking Innovations, OECD (www page) URL http://italaw.com/documents/RegulatoryExpropriation.pdf

Note 12. Vielleville, D. E. et al. (2008). "Sovereignty over Natural Resources Versus Rights under Investment Contracts: Which One Prevails?" Transnational Dispute Management, (Online-serial) 5(2). Available: http://www.crowell.com/documents/Sovereignty-Over-Natural-Resources-Versus-Rights-Under-Investment-Contrac ts_Transnational-Dispute-Management.pdf

Note 13. Ibid., p. 10

Note 14. Common Law system allows relief from contractual liability under the doctrine of Frustration. Under Islamic Law, the Imam has the right to terminate agreements with other parties if he finds that the terms are harmful to the interest of the Islamic community. Adequate prior notice to the other party is however required. Under French Law, excuse from performance of contractual obligations is recognized in cases of impossibility. See Al Qurashi, Z. A. (2005) "Renegotiation of International PetroleumAgreements"Journal of International Arbitration (On-line serial) 22(4), Available: https://is.muni.cz/www/210560/23073893/Qurashi-Renegotiation.pdf

Note 15. Amoco International Finance v. Islamic Republic of Iran, Award No. 310-56-3 (14 July 1987), 15 Iran -US CTR p. 189 at pp. 219-221

Note 16. Macedo, J. supra, note 7.

Note 17. Ibid, p. 2.

Note 18. Bernardini, P. (2008). "Stabilization and Adaptation in Oil and Gas Investments".Journal of World Energy Law \& Business. (On-line serial) 1(1), Available: welb.oxfordjournals.org/content/1/1/98.extract

Note 19. Ibid. See also Sornarajah, M. (1996). The International Law on Foreign Investment. New York: Cambridge University Press. P. 327

Note 20. Asante, S.K.B., supra note 4, P. 409.

Note 21. Sornarajah, M. supra, note 19

Note 22. Bartels, M. (1985) Contractual Adaptation and Conflict Resolution, The Netherlands: Kluwer B. V. Pp. 22.

Note 23. Bernardini, P. supra note 18. P. 101

Note 24. Ibid

Note 25. ICSID Case No. ARB/77/1

Note 26. Award of 30 November 1979, 21 ILM at p. 726 (1982).

Note 27. 17 ILM at p. 22

Note 28. Vielleville, D. E. supra, note 12, P. 13

Note 29. Yackee, J. W. (2009) "Pacta Sunt Servanda And State Promises To Foreign Investors Before Bilateral Investment Treaties: Myth And Reality" Fordhham International Law Journal. (On-line serial) 32. Available: ir.lawnet.fordham.edu/cgi/viewcontent.cgi?article $=2165 \&$ context...

Note 29a. Revere Copper \& Brass, Inc. v. Overseas Private Investment Corporation (OPIC), [1978] 56 I.L.R. 257

Note 30. Bernardini, P. supra note 18. P. 102

Note 31. Walde, T. W. (1989) "Permanent Sovereignty over Natural Resources: Recent Developments in the Mineral Sector". United Nations Natural Resources Forum. (Online serial) 7(3). Available: http://onlinelibrary.wiley.com/doi/10.1111/j.1477-8947.1983.tb00265.x/pdf 
Note 32. Walde, T. W. (1978). "Revision of Transnational Investment Agreements: Contractual Flexibility in Natural Resources Development". Lawyer of the Americas. (On-line serial) 10(2), Available: http://www.jstor.org/stable/40175798.

Note 33. Macedo, J. supra note 7. P. 10.

Note 34. Ibid.

Note 35. (Hungary/Slovakia), Judgment of 25 September 1997. (www page) URL www.icjcij.org/docket/index.php?p1=3...3...case...

Note 36. "The Applicable Law". The Journal 5-3b, CEPMLP. (On-line serial), Available: http://www.dundee.ac.uk/cepmlp/journal/html/vol5/article5-3b.html.

Note 37. Vielleville, D. E. supra, note 12. P. 3.

Note 38. Ibid.

Note 39. Feldman v. United Mexican States, Case No. ARB(AF)/99/1

Note 40. Vielleville, D. E. supra, note 12. P. 11.

Note 41. Witten, E. A. (2008) “Arbitration of Venezuelan Oil Contracts: A Losing Strategy?” Texas Journal Of Oil, Gas, And Energy Law (On-line serial) Available: http://www.tjogel.org/archive/Vol4No1/witten.pdf.

Note 42. Eljuri, E. et al. (2009) "Venezuela: On the Path to Complete 'Oil Sovereignty' or the Beginning of a New Era of Investment?" Journal of World Energy Law and Business. (On-line serial), 2(3). Available: jwelb.oxfordjournals.org/content/2/3/259.extract

Note 43. In April 2005, Venezuela's energy minister, Rafael Ramirez, announced that existing agreements would have to be converted into joint ventures, with PDVSA owning a minimum of $51 \%$, and would owe a new royalty of 30\%. When Total and Eni refused, President Hugo Chavez sent the National Guard to seize their fields. Exxon Mobil sold its stake in those fields to Repsol to avoid accepting the unfavorable terms. In response, Ramirez said, "the doors are closed to that company here." See Witten, E. A., supra note 41, P. 57.

Note 44. Petróleos de Venezuela, S.A. (Petroleum of Venezuela) is the Venezuelan state-owned petroleum company. It has activities in exploration, production, refining and exporting oil, as well as exploration and production of natural gas. Since its founding on 1 January 1976 with the nationalization of the Venezuelan oil industry, PDVSA has dominated the oil industry of Venezuela. See (www page) URL http://en.wikipedia.org/wiki/Petr\%C3\%B3leos_de_Venezuela.

Note 45. "Foreign Direct Investment for Development: Maximizing Benefits, Minimizing Costs". O.E.C.D., (2002). (www page) URL http://www.oecd.org/dataoecd/47/51/1959815.pdf.

Note 46. Ibid.

Note 47. The New York agreement of 1972 and subsequent OPEC declarations called for a timetable within which host state participation would rise from 25 to 51 per cent from 1973 to 1982 . These targets have generally been realized and, in many countries, home state participation has been advanced and accelerated above the rates and time schedules set by the New York agreement. See Asante, S. K. B, supra, note 4.

Note 48. Supra, note 45.

Note 49. Al Qurashi, Z .A. supra, note 14

Note 50 Bartels, M. supra note 22, P. 28

Note 51. Petroleum production agreement between the Government of Ghana and Shell Exploration and Production Co. of Ghana Ltd of 1974 (clause 47b).

Note 52. Article 62 of the Vienna Convention on the Law of Treaties, 23 May 1969.

Note 53. Bernardini, P. supra note 18, p.104

Note 54. Berger, K. P., "Renegotiation and Adaptation of International Investment Contracts: The Role of Contract Drafters and Arbitrators". Vanderbilt Journal Of Transnational Law. (On-line serial) 36(1347) Available: law.vanderbilt.edu/publications/journal-of...4/download.aspx?...

Note 55. Okogu, B. E. (2003) “The Middle East and North Africa in a Changing Oil Market”. International

Monetary Fund, (www page) URL http://www.imf.org/external/pubs/ft/med/2003/eng/okogu/okogu.htm.

Note 56. In Asante, S.K.B. supra, note 4, p. 414. 
Note 57. Quoted in Kahale, G. 2010. "The Uproar Surrounding Petroleum Contract Renegotiations." In Oxford Energy Forum Newsletter Nov., (www page) URL http://omanlawblog.curtis.com/

Note 58. Asante, S.K.B., supra note 4. 